$\begin{array}{ll} & \text { Etnográfica } \\ \text { etnográfica } & \text { Revista do Centro em Rede de Investigação em }\end{array}$

Antropologia

vol. 25 (2) | 2021

Vol. 25 (2)

\title{
Sustainable emotions: the front and backstages of slavery in Gorée Island
}

Emoções sustentáveis: palcos e bastidores da escravatura na Ilha de Goré

\section{Maria Cardeira da Silva}

\section{(2) OpenEdition}

\section{Journals}

Electronic version

URL: https://journals.openedition.org/etnografica/10388

DOI: 10.4000/etnografica.10388

ISSN: 2182-2891

\section{Publisher}

Centro em Rede de Investigação em Antropologia

Printed version

Number of pages: 437-464

ISSN: 0873-6561

\section{Electronic reference}

Maria Cardeira da Silva, "Sustainable emotions: the front and backstages of slavery in Gorée Island", Etnográfica [Online], vol. 25 (2) | 2021, Online since 29 July 2021, connection on 21 January 2022. URL: http://journals.openedition.org/etnografica/10388 ; DOI: https://doi.org/10.4000/etnografica.10388

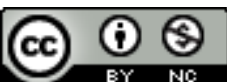

Etnográfica is licensed under a Creative Commons Attribution-NonCommercial 4.0 International License. 


\section{Sustainable emotions: the front and backstages of slavery in Gorée Island}

\section{Maria Cardeira da Silva}

More than merely symbolic, destinations of roots tourism such as Gorée Island (Senegal) are places where emotion about slavery is supposed to be experienced and displayed. UNESCO statements, political testimonies by distinguished visitors, performances of well-known African American artists and comments of tourists seem to testify this. I modestly argue that, by evoking feelings, presumably shared, about slavery in a setting that exacerbates emotions through touristic performances, the idea of international community is here re-enacted and sustained, under the principle of the universality of human rights. I believe that the global heritage regime promoted by UNESCO and other similar international platforms could be considered the strongest apparatuses to induce common belonging crosscutting national borders while spreading cosmopolitan liberal ethics and forms of cosmopolitan memory that are no longer primarily framed by the nation state. The question here, is that the very idea of international community is built with the same imagination, devices and displays and based on the same nationalist assumption of pan-cultural emotions that Anderson described for the rise of nations, but one that, paradoxically, is inter-national, made of nations: a metanation.

KEYWORDS: international community, slavery, roots tourism, Gorée Island, cosmopolitan emotions.

Emoções sustentáveis: palcos e bastidores da escravatura na Illha de Goré - Mais do que meramente simbólicos, os destinos do turismo de raízes, como a ilha de Goré (Senegal), são lugares onde se espera que a emoção despoletada pela escravatura seja experienciada e exibida. Para isso contribuem as múltiplas declarações da UNESCO, os depoimentos políticos de visitantes ilustres, as performances de artistas afro-americanos conhecidos e os comentários registados pelos turistas. O meu modesto argumento é que a ideia de comunidade internacional, baseada no princípio da universalidade dos direitos humanos é recriada e reencenada, através da convocação dos sentimentos para lugares como este. $\mathrm{O}$ regime global do património promovido pela UNESCO e por outras plataformas institucionais similares deve ser considerado o aparato mais persuasivo para a criação de um sentimento de pertença coletiva, ultrapassando fronteiras nacionais e difundindo uma ética liberal e formas de memória cosmopolita que já não são definidas em função da moldura dos estados-nação. A questão é que a ideia de comunidade internacional mobiliza para a sua construção os mesmos dispositivos imaginativos e exibicionários e o mesmo pressuposto pancultural das emoções que Anderson descreve para a ascensão das nações, embora paradoxalmente, se assuma como inter-nacional, feita de nações: uma metanação.

PALAVRAS-CHAVE: comunidade internacional, escravatura, turismo de raízes, ilha de Goré, emoções cosmopolitas.

SILVA, Maria Cardeira da (m.cardeira@fcsh.unl.pt) - CRIA, FCSH-UNL, Portugal. 


\title{
INTRODUCTION
}

\author{
$[\ldots]$ la peau qui se trouve \\ Sur les corps de Gorée \\ C'est la même peau qui couvre \\ Tous les hommes du monde \\ Mais la peau des esclaves \\ A une douleur profonde \\ Qui n'existe pas du tout \\ Chez d'autres hommes du monde \\ C'est la peau des esclaves \\ Un drapeau de Liberté \\ (Gilberto Gil, Lyrics from La lune de Gorée \\ performed in French and Portuguese)
}

If we think of the world according to the oratory of the international community and in the light of the United Nations, we could read the map of UNESCO World Heritage Sites as a huge museum, hosting unevenly distributed showcases, as an exhibitionary complex (Bennet 1995) which teaches us how to be citizens of the world and compels us to participate in its construction. This heritage regime (Bendix, Eggert e Peselmann 2012; Geismar 2015) chooses the exhibitable and visitable fragments of culture and iconizes them to celebrate a purportedly universal morality. ${ }^{1}$ The moral that steers this world is universalist, and the chart that presided over its curatorship is the Universal Declaration of Human Rights. Universal Heritage, which was institutionalized by UNESCO, thus contributes to the naturalization of an allegedly Universal Law. This is still the same worldview that we have inherited from post-World War II, specifically built to counter the excesses of nationalisms: a community built with the same imagination, devices and displays that Anderson described for the rise of nations (1983), but one that, paradoxically, is inter-national, made of nations, a meta-nation. ${ }^{2}$

Rooted in the same historical moment that defined this worldview, the idea of development - more or less seasoned with sustainability - runs economic liberalism often disguised as neo-humanitarianism in the wake of the increasing

I Heriditary regime means an understanding of heritage as governance and politics rather than simply as entity upon which governance may be wielded. In a broader sense, it implies a particular regime of truth, "a regime which is all at once material and ethical, economic and emotional, scientific and sensory [where] the moral imperative is self-evident" (Poulot 2006, summarised by Hafstein 2007: 76).

2 It should be noted that rather than being a direct offshoot of the United Nations, UNESCO stems from the European Organization International Committee on Intellectual Cooperation (ICIC). UNESCO's task was to promote peace and "change the minds of men", primarily through education and promotion of cultural diversity and understanding. The ICIC was established to create a "state of mind conducive to the peaceful settlement of international problems within the framework of the League of Nations" (Valderrama Martínez 1995: 3). 
NGOization of social care, praise for civil society and calls for values such as solidarity. At first, this occurred on allegedly underdeveloped continents and now a bit everywhere around the world in the light of new hierarchies and maps that bring into play the same old patterns, affecting new peripheral and impoverished areas.

Nation is often seen as an emotionally charged object while cosmopolitanism, or universalism, is seen as an ideal and cool as opposed to the hot emotions of nationalism (Turner 2000; Nash 2003). Transnational fluxes and platforms, NGOs and social movements, which are the most significant constituencies of belonging that crosscut national borders, were not able to displace national feeling nor erase the local and cultural bulk of belonging feelings and emotions and their individual manifestations (Nash 2003). In the absence of a global political community, the world becomes a huge stage where different kinds and scales of emotions interplay and display in a random way. Even though global exportation regimes have been approached at different levels and in different ways, the effective articulations of these two emotional landscapes - nationalist and cosmopolitan - remain greatly unexplored. Moreover, these approaches rarely actually address people as individuals or as their own enactment of these globalised and travelled emotions. I will argue here that following the tracks of current heritage regimes and the ways they propagate emotions towards the sites they nominate is a good way to make that observation. Bendix, on this issue, draws attention to the fact that "probing what tourists actually sense and feel - as opposed to think about - when visiting such sites $[\ldots]$ has so far not been researched very deeply, not least because tourists, much like anthropologists, will be logocentric in their responses." However, she agrees with Howes (2003: 58) when he says that translating sensual insight into writing remains the most effective form of representation (Bendix 2021: 530). I will be following both their views on this matter but do not aspire to find out "what tourists actually sense and feel", but to share in all modesty information as to the way they perform what they sense and feel by introducing some internet links where emotions and senses of being there are curated, performed and displayed by tourists and other visitors to one of these sites: the Island of Gorée in Senegal.

I will base my observations on three assumptions: (1) one that has been explored in the past few decades by the anthropology of performance and more recently by heritage studies, which gives agency to acts of resignification and symbolic sharing, and which in fact arises directly from Mauss and Hubert (1902-1903) and classic elation in which shared affective states (such as those underpinning magic) are eminently effective, "they do things"; (2) a second assumption that not only definitely cancels the separation between tradition and modernity but also asserts the incorporation of different worldviews, historic participations and cultural configurations in the formation of modernity 
(in the exact and appropriate sense for cases we will follow as suggested by Gilroy in his The Black Atlantic (1993); (3) and a third, which according to the reasoning of the second, proposes the free circulation of people and their actions not only within the scale of the promoters and performers of the ongoing symbolical resignification but between the terms that still nourish and differentiate these resignifications (such as memory versus history, communitarianism versus capitalism, nationalism versus cosmopolitanism, emotions versus cognition or rationality, authenticity versus staging, pardon versus redress and ultimately, culture versus society). I believe it is emotions that control the vocabulary of this entire game, since they're the ones that in fact enable it and give it apparent coherence. It is my conviction that the global heritage regime promoted by UNESCO and other similar international platforms could be considered the strongest/most powerful apparatuses to induce common belonging crosscutting national borders while spreading cosmopolitan liberal ethics. The paradox is that they are based on the same nationalist assumption of pan-cultural emotions, which is why one should view them as meta-nations.

\section{EMOTIONAL COMMUNITIES AND REGIMES}

History founded the origins of what is designated as "emotional regimes" (Reddy 2001) and "emotional communities" in what is known as the Middle Ages (Rosenwein 2006), or at least long before the creation of the nation. Meanwhile, anthropology has showed, with a great deal more noise, that the relativism in time that history denounced also occurred in space (Lutz and White 1986; Lutz 1988; Lutz and Abu-Lughod 1990; Rosaldo 1984; for more on anthropology see Wulff 2007, and on history, Plamper 2015). Both approaches have definitely destabilized any persistent idea of pan-emotions, and showed that emotions are not mere feeling states, but are governed by dimensions of cognition or rationality: the use of emotion concepts as elements of ideological practice actually involves negotiations over the meaning of events, over rights and morality, over control of resources - in short, involves struggles over the entire range of issues that concerns human groups (Lutz 1988). This being so, the importance of emotions, not just culturally but also socially, must also be taken into consideration in the formation of the principle of community and the concept of belonging through recognizing and sharing an index of social relationships. In this social constructionist approach, which takes emotion as a system of concepts, beliefs, attitudes and desires, virtually all of which are context-bound, historically developed, and culture-specific, the distinction between emotion and interpretation of emotion is too sharp: both are interpretations, and the same concepts often enter into the structure of each (Solomon 1984). And thus, if we consider the hard version, we can say, as Solomon does, that emotions are judgments (1988). 
In short, without denying the possibility of finding the same emotions in different societies, both history and anthropology converge in the role they assign to emotions in the configuration of imagined communities, and political science and philosophy soon accepted the same conclusion. There is no reason to think that this has changed in the global world today. On the contrary, the role of emotions has been propitiated, at different levels, through the lubrication and multiplication of platforms of global dissemination and communication.

Meanwhile, Dixon points out that "emotions" did not exist prior to the eighteenth century, when in a process of creating a secular psychological category, emotions began to replace previous categories such as appetites, passions, sentiments and affections $(2003,2012)$. This further complicates matters by mimetically shattering (without weakening it) the actual relativist argument: not only are emotions culture-specific, i. e., experienced in a relative manner, but the actual category defining them is also culture-specific in itself and a localism that has been globalized (Santos 1997) just like the principle of human rights. Consequently, their alleged universalism could never spring from a natural principle but, at best, a historical-cultural process of naturalisation.

Historically in the world that Dixon refers to, management and representation models as well as the constitution of emotional regimes are closely connected to structural changes (for instance, the privatisation of emotions is connected to industrialisation (C. Stearns and P. Stearns 1988) and/or the exaltation of emotion towards the development of the service sector (Gerhards 1989). However, it could be argued that there have never been a-emotional organisations, any more than a-emotional societies.

And ultimately, this brings us again to the point where the very existence of "authentic emotions" must be called into doubt, because if there is no such thing as an a-emotional society neither can there be a society where emotions are not controlled and managed. According to Rosenwein, the history of the West is the history of increasing emotional restraint (Rosenwein 2006). What has changed today is the fact that far from "letting emotions out", the present dominant regime recognizes their existence and value while simultaneously demanding their use in accordance with norms of an "intelligent" management of emotions (Sieben and Wettergren 2010).

It is within this evolutionary framework that we can situate the patrimonial regime of UNESCO, the major international instrument for safeguarding the world's heritage as well as other national heritage regimes, while refuting the idea of the purely rational bureaucratic organization in the classic Weberian sense and highlighting the myriad ways in which organizations can be seen as emotional arenas (Fineman 1993; Fineman 2000 cit. in Sieben and Wettergren 2010). ${ }^{3}$ 
In this paper I modestly argue that by evoking emotions, presumably shared, about slavery in a setting that exacerbates emotions and where a performance is staged mainly for the sake of tourism, the idea of an international community is recreated and sustained under the principle of the universality of human rights. But more than merely symbolic, destinations of roots tourism places such as Gorée Island, are places where emotion about slavery is supposed to be performed and experienced. A powerful stage is erected on which various characters appear and play a drama that re-enacts struggles over good and evil, debt and forgiveness, control of resources, rights and morality, throughout the whole world, thus presuming, while reinforcing the presumption of, the existence of an international community of emotions. This is the way heritage regime works: it converts cultural practices in resources for administering populations and, in addition to performing themselves, they perform affective relationships and identities. They perform, after all, the subject position under the global community (Hafstein 2007: 95).

\section{EMPLACEMENT: THE STAGE}

There is no way to get to the island except via the ferry dock, ${ }^{4}$ unless you swim, which is what many of the young people do, imitating the Dakar-Gorée swimming race like other African swimming championships. Whichever the case, when one gets there, the first view over the island is stunning and photogenic in its shape, colour and scale. It immediately touches on the perverse aesthetics of colonial nostalgia (Gupta 2009; Stoler 2008; Bissell 2005; Werbner 1998; Rosaldo 1984).

Gorée is an island 17 hectares in size located 2 miles off the coast of Dakar. It has a population of 1500 , most of whom are young people, but its floating population more than doubles during the day with the influx of tourists and local women that follow them around to try and sell souvenirs, necklaces and other bits of jewellery. Once a week, they are joined by groups of students on school trips organized by teachers in compliance with the official set pedagogical programme.

Unlike tourists, these students are not required to pay an entrance fee as soon as they disembark from the ferry after the twenty-minute journey. ${ }^{5}$ The

[continuation] Nations Organisation on the one hand, and the celebration and institutionalisation of intangible heritage on the other. But this is not the place to do so.

4 "One day trip to Gorée Island", 2009, 8'06". Fieldwork video by the author @ CRIA/Maria Cardeira da Silva. Available at < https://youtu.be/uAysQQvaCcU > (last access June 2021)

5 I tried insistently but in vain to get precious data as to the precise numbers of travellers that only the autonomous Dakar Port authorities, through the Dakar-Gorée Maritime Liaison Office (LMDG), could provide me given that tourist tax or fee on leaving the dock is not regular. I was further disheartened when the staff at the town hall explained that they themselves had tried unsuccessfully [continues] 
size of the crowds on the island is not larger only because the number of tourists and students is controlled in order to coincide with the ferry timetable, which is usually every hour and a half.

The visit can include the Museum of Women's History (Henriette Bathily), the History Museum in Fort d'Estrées, which once kept guard over the river mouth, the Museum of the Sea and the fortress. But the true point of pilgrimage is the House of Slaves and there is rarely time for anything else.

On the opposite side of the ferry dock is the fortress, the old stronghold in the north at the top of a steep slope from where Dakar can be seen and where there is a small replica of the Gorée Memorial, which won an international competition organised by UNESCO. On the way up there are ateliers and stalls selling paintings by local artists who try to detain the slower walkers among the tourists. In the underground communicating areas of the old military installations on the slope, Baye Fall youths have clandestinely settled in. They belong to a branch of a Sufi brotherhood of Murides and have taken a special and syncretic form of young Senegalese's popular culture by incorporating Rastafarian features, such as dreadlocks, and later New Age traits. Tourist guides and residents in the lower area of the island have ambivalent feelings about the Baye Fall: they consider them social outcasts who rob and cause minor disturbances and are thus responsible for the apprehension and complaints of some tourists as they're feeling insecure due to the harassment - sometimes sexual ${ }^{6}$ - they suffer as soon as they land on the island. ${ }^{7}$ Apart

to get the numbers. This shows the tension, which was later confirmed, that exists between the state companies involved, the central government itself and the Commune de Gorée, regarding the management of the island's resources and infrastructures. I will not linger on the matter now but it influences, among other things, the emotional atmosphere on the island.

6 Not even my connections with the Institut de Gorée and the Centre pour la Démocratie, le Développement et la Culture en Afrique - and I wish here to thank them for their logistic support (which, despite my protestations, led to my paying for a guard to remain at night in the house I rented) -, nor my initially diplomatic but then peremptory refusal of offers of sex seem to have been of any avail in changing the impression of some men, often young ones, that I was a foreigner seeking a sexual adventure when they persistently approached me during my entire stay. I will, however, highlight the amiability and tranquillity of most other encounters and meetings, which, I must admit, took place in an atmosphere profoundly marked by the crystallisation of discourses and performances produced for the sake of tourists and NGOs. Just as in Bali (Picard 1990), in Gorée tourism is culture.

7 The same discomfort and criticism appears on the Internet where people argue what are the "true or false" features: "Cet aspect pittoresque du mouridisme séduit chaque année de nombreux doux-dingues européens confrontés à la vacuité spirituelle que connait l'Europe. Des jeunes et moins jeunes trouvent rigolo ces croyants rasta habillés en boubou multicolore et ils se convertissent au mouridisme comme leur vieil oncle hippy s'est converti au bouddhisme en mai 1968. [...] Seuls les touristes, la plupart un peu cons et ignorant les usages du Sénégal, fréquentent ces tribus d'inactifs qui gravitent souvent autour d'eux". Consulted at < http://www.senegalaisement.com/senegal/rastafarisme_au_senega 1.php > (no longer available). See also Clément (1999), and, above all, for a less emotional approach, Ngom (2012). For a good understanding of relations with tourism and other types of tourism in the area of Carabane, see Leitão (2012). 
from the Baye Fall Brotherhood, Sunni Muslims, who are the majority, as well as Christians, live on the island, which seems to have the same percentage of ethnic groups, mostly Wolof, as the country on the whole.

The pretty houses with gardens on the island mostly belong to foreigners, especially French, who rent them out to tourists who wish to spend the night there. Only their patios are open to visitors during the biannual Regards sur Cours Festival, during which Senegalese paintings are shown in the open air as part of an international event within the framework of the island's cultural activities. Apart from this, there are very few hotels and this is one of the problems the inhabitants point to as the reason for the scant economic return they get from the daily invasion of tourists. They complain that the plan to renovate the former French governors' palace, Relais de l'Espadon, was abandoned. This is a charming colonial building on the Place des Droits Humains, next to the Town Hall and in front of an ancient baobab tree, which is used for putting up regulations and notices.

The bulk of the population lives in the ruined old barracks that have been subject to heritagisation as have so many other sites and islands and have become an African tourist destination. The main problem here is housing and re-housing. ${ }^{8}$ 65\% of the housing in Gorée consists of state-owned old colonial buildings that are occupied by a moving population of squatters, some who have moved in more recently than others. As in so many other historical centres, we sense the daily tension between urban sanitation plans leading to management of visitability spaces, understood to be valuable for economic development, and social management of the resident population, understood as a value for so-called sustainable development. It could be for this reason - and for having managed since 2002 a locality with social and ecological concerns for three mandates - that Gorée is proud to be the Commune with the greatest number of associations per square kilometre in Senegal. ${ }^{9}$

The mayor of Gorée belongs to the minority ecologist party and happens to be a nephew of Senghor (the former charismatic president of Senegal, a poet and inspiration behind the concept of negritude). He's available to see people who live in the municipality once a week and it was in the waiting room of the town hall that I got to know Josephine one Saturday morning. Josephine (not her real name) is one of the roughly 1500 residents of the island, and like most of them, she was living in a small house in disrepair. Afterwards, Josephine invited me to her house and told me her story. She is divorced and lives in a room of a house she shares with other families. She had gone to the town hall

8 See Almeida (2012), for instance, for the Island of Mozambique, and Bissel (2005), for Zanzibar.

9 There are at least ten associations for cultural, ethnic, sporting, social and economic activities (ASC Coumba Castel, AJAG, AFI Gorée, Association des Jeunes Halpulaar, AMAG, AMEEGO, Association Africa Capoeira, Gorée Assistance, GIE la Signare, Association Habitants Castel...), and the town hall is promoting decentralised cooperation for their development. 
to ask the mayor to let her demolish a wall to make a small handicraft shop for her to run with her unemployed son. Most women on the island survive by this means and have to compete with women who come from Dakar every day. Her request was turned down on the grounds that this would go against the urban policies of Gorée. At first she spoke angrily against the town hall, government, tourists and people who came with their pencils and notebooks to speak at places like the Université des Mutants (the famous university that Senghor founded with Roger Garaudy on the island). ${ }^{10}$ Then, smoking one cigarette after another, she attributed her sadness, emaciation and despair to the tragic event that had taken place some years before: her $2 \mathrm{l}$-year-old daughter had been hit by a boat and killed when she was swimming in the bay where tourists' filled ferries from Dakar dock on the island. She pointed to a framed photograph of her daughter hanging on the wall. Next to it, in a nice frame, was the certificate of Joseph N'Dyaie, the charismatic curator of the House of Slaves often mentioned in international media until he died in 2009, who was, Josephine told me later - with what I thought was a look of pride -, her father and her daughter's grandfather. ${ }^{11}$

\section{MISE EN SCENE}

As in so many other sites, heritagisation or façadism, which introduced colours hitherto unknown in Gorée, ${ }^{12}$ has lent Gorée a certain colonial semblance again by using Provence tiles and planting the proverbial bougainvillea; but it also concealed the misery of most of the population. This staging began in the colonial period even before the island as a whole was classified in 1944 as a historic site by the Commission supérieure des monuments historiques et des arts indigènes, and after about 90 buildings had been restored and the power and water networks modernised. Gorée Island was actually used by France as a lab for its cultural policies regarding safeguarding heritage and colonial tourism. ${ }^{13}$

10 L'Université des Mutants is an international centre for meetings and conferences which was founded in 1979 through the initiative of President Léopold Sédar Senghor and the French writer and philosopher, Roger Garaudy. Since the $3^{\text {rd }}$ of June 2017, the university building has been the social headquarters of the Fondation Mondiale pour le Mémorial et la Sauvegarde de Gorée. See further ahead.

11 I never managed to check whether this genealogy was descriptive or merely classificatory: although very kind, Josephine was full of rage when she spoke about - without differentiation - "tourists and people who come with their pencils and notebooks to speak at places like the Université des Mutants". It made me suspect that the inter-subjectivity that framed our encounters was conditioned both by her essentialist vision of foreigners and by the consequent suspicion it aroused in me.

12 The houses would have been painted white and the wood green as shown in an engraving by the artist d'Hastrel in 1839; it was towards the end of the nineteenth century that houses began to be painted in pink ochre and yellow (Ricou 2003: 98, 113).

13 For the history of the staging of the previous UNESCO classification for the Island, see Bocoum and Toulier (2013). 
Senghor (Léopold Sedar Senghor, Senegal first president and uncle of Gorée's mayor, whose family name allegedly derives from the Portuguese word "senhor". Senghor himself said so in his poem Elegie des Saudades ${ }^{14}$ ) was not against this heritagisation process: while heritage was not the central subject of his racial constructivism, which focused more on rhythm and dance to build its ideal of negritude, ${ }^{15}$ the strategic essentialism displayed in the first World Festival of Black Arts that he promoted in 1966, called the public's attention to African heritage and made Gorée an important setting for a festival of light and sound, Les féeries de Gorée, where the history of Senegal and Gorée's role in the slavery trade were enacted (see Bocoum and Toulier 2013). The negritude movement and its connections with other black affirmation movements such as Harlem Renaissance and its subsequent developments placed western Africa (especially major slave trade centres like Ghana, Gambia and Senegal) at the centre of black diaspora belonging maps. Since the 1970s, literature and then films followed the footsteps of slave heroes (such as Kunta Kinte, the character in the novel Roots: The Saga of an American Family by American author Alex Haley), ${ }^{16}$ inspired African American and Afro-Caribbean tourists to travel to the western coast of Africa and visit former slave fortresses and other built heritage sites in order to mourn as well as celebrate the memory of their ancestors, or as West caustically defines it: "conspicuous compassion" or "recreational grief" (West 2004: 11).

In 1972, Senegal ratified the convention concerning the Protection of World Cultural and Natural Heritage and three years later included Gorée Island in its inventory of historical monuments thus preparing its inclusion on the list of World Heritage Sites in 1978. This was done according to UNESCO criterion (vi): "The Island of Gorée is an exceptional testimony to one of the greatest tragedies in the history of human societies: the slave trade. The various elements of this 'memory island' - fortresses, buildings, streets, squares, etc. - recount, each in its own way, the history of Gorée which, from the 15th to the 19th century, was the largest slave-trading centre of the African coast." 17

\section{SANCTUARY}

If roots' tourism is understood as pilgrimage (Graburn 1989; Eade and Sallnow 1991; Morinis 1992; Badone and Roseman 2004), and heritage as the new

14 Available at < https://www.deezer.com/fr/track/102697154 > (last access June 2021).

15 "This ordering force that constitutes negro style is rhythm. It is the most sensible and the least material thing. It is the vital element par excellence. It is the primary condition for, and the sign of art, as respiration is of life; respiration that rushes or slows down, becomes regular or spasmodic, depending on the being's tension, the degree and quality of the emotion" (Senghor 1964: 296).

16 See Bellagamba (2009) for a similar process in Gambia.

17 Available at < http://whc.unesco.org/en/list/26/ > (last access June 202 I). 
sacred (Richard and Caron 2014; Meyer and Witte 2013), then the House of Slaves is the sanctuary for those who come to Gorée. And like most sanctuaries, this one is contaminated by controversy as is, in a similar manner, the heritagisation process of the island in general, the sacralisation of the House of Slaves - which allegedly belonged to Anne Pépin, a signare born around 1758, married à la mode du pays to Bernard Dupuy, a French trader from Bordeaux, and mistress of the Chevalier de Bouffiers, poet and governor of Senegal. ${ }^{18}$

The House of Slaves was promoted first by the French in 1932 when Robert Gaffiot describes one of the maisons négrières in his tourist guidebook Gorée, capitale déchue, in which he gives a dramatic account of the way this space was used as a warehouse and how the doorway - later called the Door of No Return - opened out onto the ocean and served as a boarding gate for slave ships sailing to the Americas. This favoured the removal of the dead bodies of those who failed to survive the "supplice de cette vie atroce". This description is even more tragic and distressful in Pierre-André Cariou's account. ${ }^{19} \mathrm{He}$ based it on factual (and a few uncertain) reports saying that the House of Slaves was included in the colonial tourist and pedagogical visits to the island in the early 1950s. It stands in front of the Musée Historique de l'Afrique Occidentale Française, another former slave house, where one of the rooms was "consecrated" to the history of slavery, celebrating its abolition by France a century before in 1848 .

If it is true that the explanation of the symbolic thickness of the House of Slaves is to be found over the stratigraphy and sedimentation of literary depictions through time, one should also take into consideration (following Singleton 1999) its spatial dimension - emplacement, configuration and size to justify its emblematic effectiveness. Facing the Atlantic, the two-story house is no more than 600 square metres in size. The second floor is accessed through stairs from a common patio: the upstairs floor would have been reserved for the owners, and downstairs were the slaves' dungeons that opened onto the sea through a narrow door. According to some authors (Hinchman 2006; Araújo 2014), these configurations and dimensions would be closer to the model of indigenous domestic slavery than that of the Atlantic slave trade. But this memory diversion of the Gorée House of Slaves (which actually encompasses the controversy around Gorée's real role in the Atlantic slave trade) gave room

18 Signare comes from the Portuguese term senhora (lady), so the practice of taking local wives to facilitate trading relationships probably dates back to the arrival of the Portuguese on Gorée in 1444. However, signares reached the height of their social status in the late 18th century and their epoch ended with the foundation of Dakar in 1857. In 1767, Caty Louette, signare de Aussenac de Carcassone, had working in her service 27 gourmets and 43 rapareilles (sic; domestic captives, words of Portuguese origin as well; Ricou 2003: 52, himself a descendant of Caty Louette. See below).

19 Cariou, Pierre-André, Promenade à Gorée (Sénégal), typescript, 1951-1952, quoted by Bocoum and Toulier (2013). 
to the weightiest device in support of a moving narrative: that of confinement. ${ }^{20}$ Confinement, especially for a throng of people crammed into such a small space - which is the first impression that visitors experience - immediately congregates and activates all our biological senses, playing an essential role in emotional processing, learning and interpretation of the plot.

\section{PRIEST AND CURATOR(S)}

Joseph N'Diaye - grandfather of Josephine's daughter and former curator of the Slaves House until he died in 2009 - used to start his guided tour in the patio, ${ }^{21}$ emphasizing the fact that 200 slaves were forced to live in such a tiny space on the ground floor - 15 to 20 slaves in chains in each cell, young women and children, but men and women separated - and under deplorable sanitary conditions. Then he lifted up iron gang chains and shackles to show how heavy they were and explained how the slaves were kept seated against the walls or lying like "canned sardines" and freed only once a day for a lavatory break. The visit to the house proceeded through the ground floor, stopping at each of the tiny, bare, dark and wretched cells to describe the specific atrocities and humiliation inflicted upon women, girls, children and men. This part of the visit, together with the curator's enactment, finished at the climax point of the Door of No Return, where stories of plague, dead bodies being thrown into the sea and sharks swimming close by attracted by the smell of blood - a smell that, according to some, still lingers - framed the visitors' gaze over the Atlantic and Middle Passage. After a while, visitors were allowed - and, to my knowledge, still are - to go upstairs on their own and visit the bright, clean, painted and renovated rooms where "it's hard to imagine how slave owners could live indifferent to all the suffering", and its verandas opening onto the sea, framing a contemplative and leisurely gaze over the ocean. The upstairs floor is decorated in a manner typical to a museum, although with scant information, leaving room for a personal interiorisation of the much stronger narrative on the ground floor. The House of Slaves is a space of embodiment of an experience and not a space of interpretation.

Joseph N'Diaye was a big man with a powerful voice and sense of drama. One can still watch his performance and curated description in several videos on the Internet. ${ }^{22} \mathrm{~A}$ former non-commissioned officer in the French colonial army, N'Diaye became the guardian of the House of Slaves. According to

20 This reproduces - on smaller scale and higher density - the "island" confinement itself, which plays an important role in facilitating its objectification and materialization and subsequent conversion as a case study, a "heritage site", a pilgrimage destination and a/or "tourist attraction".

21 Records of this can be found in different formats from books to internet videos and other registers.

22 Available at <https://www.youtube.com/watch?v=kRg39A5pjTo\&list=PL9e4LpsBs7K-XTAZVm MBUHf6v4kYk-VSt\&index $=3>$ (last access June 2021). 
Emmanuel de Roux, who dedicated part of his work to demystifying the House of Slaves "myth" (de Roux 1996), it was due to his undeniable talent that the myth emerged and grew more authoritative (even for UNESCO) than "history".

As Araújo acknowledges elsewhere, "reproducing, feeling, and sharing the experience of enslavement was and still is a hard task that historians are not able to perform. [...]. The enslavement experience becomes accessible only when an individual such as N'Diaye plays the role of mediator, by becoming an agent who transmits the experience of the victims who are no longer there" (2010: 153). One may wonder, I should add, to what extent oral transmission (something that N'Diaye clearly cultivated aesthetically in his performances, not neglecting its rhythm as he spoke) - a more "African" way of transmitting the past, closer to the victims' cultural "reality" than history - has contributed to authorising his narrative. This appears to have been confirmed by the fact that UNESCO itself endorsed N'Diaye's account, and that Senegal's ministry of Culture and Cultural Heritage officially recognised it by naming him a Living Human Treasure in 2006 - a designation that, according to UNESCO, should honour "persons who possess to a high degree the knowledge and skills required for performing or re-creating specific elements of the intangible cultural heritage". On the other hand, it is interesting to note how the conjugation of these two facts somehow allows UNESCO to escape the academic debate regarding the "true" role of Gorée in the slave trade, which could belie the consistency of including it on the list of World Heritage sites in 1978 "as the largest slave-trading centre of the African coast." ${ }^{23}$ Subsequent curators of the House of Slaves have adopted Joseph N'Diaye speech to an almost literal extent. ${ }^{24}$ Furthermore, several young people on the island reproduce it nowadays for tourists, who later put it on the Internet as emotionally charged tributes to their ancestors. ${ }^{25}$

The UNESCO Living Human Treasures programme was "aimed at encouraging Member States to grant official recognition to talented tradition bearers and practitioners, thus contributing to the transmission of their knowledge and skills to the younger generations". One should, however, note that this programme is framed within the Safeguarding of the Intangible Cultural Heritage Convention, and therefore conflicts with World Heritage nominations, where "factual" evidence is mandatory and Intangible Heritage "truth" is, by definition, intangible i.e., non-material//incorporeal. In this sense, as François Richard ${ }^{26}$ explained in the Washington Post on the occasion of

23 Available at < http://whc.unesco.org/en/list/26/ > (last access June 2021).

24 Available at $<$ https://www.youtube.com/watch? $\mathrm{v}=$ AwIus0ICPoM $>$ (last access June 2021).

25 Available at < https://senego.com/video-emouvante-lenfant-fait-rappeler-joseph-ndiaye-de-liles-de -goree_382548.html $>$ (last access June 2021).

26 Available at < https://anthropology.uchicago.edu/people/faculty/francois-g-richard > (last access June 2021) 
President Obama's visit to the island in $2013,{ }^{27}$ the House of Slaves was erected as a sincere fiction and mobilized as a memento.

\section{INTERNATIONAL PLAYERS}

Over the past 20 years, the history of the Atlantic slave trade has been incorporated into the public memory in several countries on both sides of the Atlantic. In 1992 in what the Roman Catholic Church called purification of memory at the start of the third millennium, pope John Paul II ("the African Pope") apologised in the House of Slaves at Gorée Island for the role played by the Roman Catholic Church in the period of the Atlantic slave trade. Since then, Hillary and Chelsea Clinton (1997), Bill Clinton (1998), George W. Bush (2003) and many others, including the current president of Portugal, Marcelo Rebelo de Sousa, have also condemned the wrongdoings of the slave past, but without apologising. ${ }^{28}$ It was in this setting of condemnation and celebration of the memory of slavery that Barack Obama also spoke to the world in 2009 on the spectacular stage that is one of the Ghana castles. ${ }^{29}$ Barack Obama's speech was not very fervent and this was perhaps deliberate. Nor did it have to be: his negritude (although his roots are not in slavery as are Michelle Obama's) and his nationality were strong enough factors to arouse the required emotion in a bellicose landscape where from behind the cannons one can imagine the dramatic voyage that Gilroy (1993) places at the heart of the formation of the African diasporic identity and cultural history. Obama used a pedagogical style when speaking, and as usual he was informal when he talked about the importance of the experience of the visit for his daughters Malia and Sasha. This was the tone pursued by Michelle on their next trip to Africa, which took them to Gorée Island in 2013. On this more recent trip, Michelle took the place of the narrator of a journey she chronicled in an "emotional" dairy published daily on the White House website. ${ }^{30}$

It may be useful here to mention Ebron's thoughts about a journey/pilgrimage to Gorée sponsored by MacDonald's as a marketing strategy (1999). Just as in the case of sponsored culturalism that Ebron examines, if globalization is the corporate search for universal markets and political audiences with its necessary dream of a united globe, its best tool is still the marketing campaign

27 Washington Post, June $28^{\text {th }}, 2013$.

28 It is said that the ferry that links the island to Dakar was stopped, and offices and businesses closed for the day during Bush's visit. The inhabitants were forced by the American security to leave their houses from 5 am to 12 am with everything open, including wardrobes, to be searched by special dogs brought from the US.

29 Available at < https://www.youtube.com/watch?v=YBYP9RIzgPs > (last access June 2021).

30 Availableat<https://obamawhitehouse.archives.gov/blog/2013/06/27/flotus-travel-journal-visitingGorée-island $>$ (last access June 2021). 
that appeals to particularistic cultural identities: Baraka Obama, on his journey to Ghana, was speaking to the world, but as an American (as he first mentions in his speech) and an African American. In Obama's second journey to Africa, Michelle's genealogy and gender were remembered to create a more authoritative - albeit emotional - report: Michelle's genealogy is far more relevant to most African Americans than that of her husband, the son of a white American mother and a black father from Kenya. On the other hand, the fact that she is a woman (and, at the time, the First Lady) allowed her to display emotions publicly from a privileged position in a sanctioned and safe manner.

Other presidents of different nationalities, such as the president of Brazil, have provided more spectacular performances than the Obamas. Lula da Silva, as the pope and Mandela are said to have done, cried at the Door of No Return in the House of Slaves in Gorée. As Globo News reported: "Lula, his eyes brimming with tears, listened to the secretary for the Promotion of Racial Equality, Matilde Ribeiro, deeply moved, give her speech. When the minister of Culture, Gilberto Gil, was invited to speak, he sang the words of La lune de Gorée" ${ }^{31}$ At the ceremony with the then president of Senegal, Abdoulaye Wade, there were tears in the eyes of Gilberto Gil, Matilde Ribeiro, the former minister Benedita da Silva and most of the members of the Presidential Committee. Lula said, "I had no responsibility for what happened in the $16^{\text {th }}, 17^{\text {th }}$ and $18^{\text {th }}$ centuries, but I think it is a good policy to say to the people of Senegal and the people of Africa: We apologize for what we did here to black people. When a terrible historical mistake is made, as in the case of black people and Jews, the pope (John Paul II) teaches us that it is easy to ask forgiveness". ${ }^{32}$

Although Ebron (idem) mentions the exclusion of white tourists in the group sponsored by MacDonald's that she accompanied to Gorée, and Edward Bruner (1996) in his short essay on Ghana Fortress also attests to animosity between white and black tourists, the political performance around Lula's visit emphasizes the experience of negritude, which widens out to include Lula himself, who the Senegalese president called the first "black" president of Brazil. Lula held a metal ball that had once been tied to a slave's ankle and tried on an iron chain in the House of Slaves. "The pain of slavery is like a kidney stone. There's no point in talking about it, it has to be felt. It's only by standing here that we understand the enormity of what these people endured during those

31 La lune de Gorée ("The moon of Gorée") - by Gilberto Gil and Capinan, < https://www.youtube.co $\mathrm{m} /$ watch? $=6 \mathrm{VylZM} 6 \mathrm{MzKK}>$ (last access June 2021). This music is frequently used to frame tourist experience of the island in different videos shown on the Internet. Artists from Brazil come to Gorée Island to compose fusion versions with local performers and film them: e.g., Ligiana e Ameth Male La lune de Gorée, available at < https://www.youtube.com/watch?v=H2rrozWUS3E > (last access June 2021).

32 Folha de São Paulo newspaper, April 15th 2005. 
three hundred years", 33 the Brazilian president said, using a (bizarre) physical metaphor of inflicted pain to validate universal suffering, complementing emotion performed by his black minister of Culture, and his secretary for the Promotion of Racial Equality and his former minister for Social Development (both black and a woman).

\section{GLOBAL EMOTIONS AND CITIZENSHIP}

Heritage and tourism articulation enables two of the main pillars of liberal ideas of development: economic growth and self-engaged civil education (as museums once did for nations). Investment in tourist cultural sites aim to convert them into spectacular scenarios and stages where universal values are displayed and stories are plotted out; but more than that, it is where citizens can play their own dramatic role framed by choreographies of conformity. The visibility and scope of these global stages is magnified and multiplied by the new scopic regime of modernity with digital knowledge and display, and the induced impulses for self-performance and exhibition on screens of the gregariousness of compulsive self(ie)-networking (Lepecki 2016). Tourists visiting the House of Slaves often display the experience of pain that these sites arouse (as in the case of a video on YouTube that shows a man crying convulsively in the House of Slaves, the emotional effect of which is heightened enormously by the soundtrack of Gladiator that is superimposed over the video). One of the comments of the video says:

"This brought me to tears. I took a DNA test a few weeks ago and I just got the results today [...] most of my ancestry is European and you wouldn't know it by looking at me but I was surprised to find out that I also have a small percentage of Senegalese blood. I can now identify with this man's tears, but I also have the strength and hope from God Almighty who gave my ancestor the courage to survive such terrible injustice. Peace!"

References to DNA are common on YouTube - as in the video Honoring the Ancestors: Pouring Libations at the Point of No Return, Gorée Island ${ }^{34}-$ and in the genealogic burgeoning industry which now provides ancestry test kits (along

33 Idem.

34 Available at < https://www.youtube.com/watch?v=RqZk5TrDLDI > (last access June 2021). This is a video of Queen Mamma Africa and the S Hip-Hop Delegation (some of them wearing t-shirts with Dubois picture). The episode of a black woman in spirit possession seems to have been triggered when a white visitor said to her son that Negros had been imprisoned because they misbehaved. At the end, Mamma Queen Africa, the spiritual leader of the group, offered a universal prayer to "the god who creates the heaven and earth who comes in many names". 
with t-shirts and ancestry gifts) ${ }^{35}$ at accessible prices (between 200 and 300 US dollars) to "find your tribe", thus increasingly feeding roots tourism. ${ }^{36}$ The fact that many black public people are engaging in those roots quests (see, for instance, Oprah Winfrey, Chris Rock or Chadwick Boseman) has contributed to a growing number of African American visitors to Africa. In extreme situations, visitors experience spirit possession and feel the real pain of their ancestors. ${ }^{37}$

Records of the same emotions can also be found in the visitors' book in the House of Slaves in Gorée Island. The written comments underscore the sense of being there (that must be affirmed, contrary to videos that are evidence in themselves) which the House of Slaves has commodified, providing pilgrimage certificates, some of which are later displayed on the Internet. Some comments in the visitor's book seem militant in their insistence on preserving memories, which merge with notions of safeguarding and rescuing Africa, like the one in which the famous Guyanese-born American film and television actress, CCH Pounder, makes an open call to preserve the House of Slaves in Gorée. ${ }^{38}$

The commoditization of memory of Diaspora does not end in Gorée. Many Afro-American diasporic artists besides Gilberto Gil, whether they have Senegalese roots or not, have turned the island into an icon of negritude to export in a variety of performative formats, such as music, dance and film, converting the emotions experienced there into inspiring and visual material. We cannot examine here this profusion and diversity of visitors that regularly return to Gorée even if only at the time of the great Gorée Diaspora Festival that the Senegalese government promotes every year. But in some cases, it is not just the memory of Gorée but also that of their local guardians that gives substance to artistic products. This is the case of Pierre-Yves Borgeaud's film, Return to Gorée. The story of the transatlantic journey of jazz, with Yousou N'dour playing the lead, includes a tribute to honour the charismatic curator of the House of Slaves, Joseph N'Diaye, as the guardian of African memory and authority about the Diaspora as described in the film.

35 Available at < https://shop.africanancestry.com/ > (last access June 2021).

36 Actually, genealogy industry has expanded successfully featuring tourist products: it has created tourist destinations based on the "outcomes" of its original products (DNA test), and thus merged with genealogy tourism.

37 Available at < https://www.youtube.com/watch?v=RRSGknxiOgk > (last access June 2021).

38 On the occasion of the Plexus International travelling event "Erosions and Renaissance Show" in May 2008; available at < www.youtube.com/watch?v=F7Ber3IJAfI > (last access June 2021). CCH Pounder is married to the Senegalese anthropologist, Boubacar Kone, the founder of the Boribana Museum in Dakar for the study of cultures of the African diaspora. 
ANGER, FRATERNAL FRIENDSHIP AND FORGIVENESS:

A UNESCO REMIX

The whole paraphernalia of these means, forms and circuits raises awareness of the wide range of emotions that converge on and emerge from Gorée and are made authentic by the experience of being there. On their return to Gorée, some of these transnationalised performances have greater effect than others on the local residents, especially the younger ones. The world-famous Daraa J ("School of Life") rap group have retained in their repertoire a long speech, with no music, that the old curator Joseph N'Diaye delivered about slavery and which they present at the start of their international concerts. I found it in their album Xalima ("Quill and Ink"), 39 and on cell phones and (by then) MP3's belonging to many young people in Gorée. In this case, it seems that it is the transnational voyage of the Senegalese Daraa J tours that transforms Joseph N'Diaye's message into an authoritative one for local young people. Daara J extended this activistic trend to include other current concerns, such as massive emigration and struggles against corruption giving a global voice to a significant part of Senegalese youth.

In 1994, UNESCO launched the Slave Route Project in Ouidah (Benin), a programme that supports, among other things, the setting up of structures to develop "places of memory tourism". ${ }^{40}$ It is used when requests are made for the heritagisation of different sites in Africa. African countries involved in similar heritagisation processes have undertaken to set up networks and to lobby UNESCO committee meetings with the aim of getting African monuments accepted as World Heritage. It was within this framework that the classification of Cidade Velha de Ribeira Grande in Cape Verde as World Heritage was proposed to UNESCO. I attended a seminar in June 2008 in Gorée, just before the submission of the application package that dealt with this and the importance of South-South Cooperation (as it was then designated) and the role that the heritagisation of slavery could have in challenging tangible thus eminently colonial - heritage that was being hyper-valued by UNESCO in Africa. At the same seminar, concomitant discussions regarding the twinning of the towns of Gorée (Senegal) and Cidade Velha (Cape Verde) were using kinship vocabulary, as is common in this type of political procedure, with Cape Verde (represented by its delegate, the mayor of Cidade Velha) calling Gorée its elder sister (since UNESCO's classification of Gorée, like that of the Ghana

39 Available at < https://www.youtube.com/watch? $v=$ st7kt2WPn54 > (last access June 2021).

40 "By appropriating the concept of 'the route', and by bringing together the various fields of competence of UNESCO (education, science, communication and culture), the intention of the project was not only to study the itineraries of inhumanity, but also to explore the indelible interweaving of new cultures and identities born of the intercommunication of relations, admittedly shackled by chains, but nonetheless enriched by the links woven among people and individuals from one continent to another." (UNESCO 2014). 
fortresses, dates back to the end of the 1970s). ${ }^{41}$ The final debate at the seminar, also attended by students from the Dakar School of Architecture, was lively, even rather heated, and revolved mainly around the fact that heritage rehabilitation in Africa was in the interest of its "financial backers". It grew further inflamed when notions of "debt and reparation" were brought to the arena of debate as one of the young students suggested that it should really be colonizing countries that had to pay Gorée for the rehabilitation of this type of heritage, which was in remembrance of the oppression that local people had endured for centuries. As in many other sites under heritagisation pressure, these feelings divide populations and exacerbate the experience of disaggregation (see, for instance, Collins 2013 for Bahia in Brazil).

Actually, the discontentment goes hand in hand with other forms of re-uttering memory and taming emotion currently taking place in Gorée, even if this means an entanglement of contradictions. As we have seen, signares (the French used to refer to them as negrèsses de qualité) are important icons of the island as they are the main local protagonists and visual players and displayers of Gorée as a depiction of "Creole culture". Like in other places, this depiction was mobilised as an emic concept to describe social relations and the historicity of social life, especially activated to source postcolonial nationalisms (see Picard 2011 on Reunion Island). In the process, gender and racial violence, together with class and inter-ethnic violence, is obscured or diluted in water-colour pictures to present the island as an idyllic and almost magical result of multi-layered cultural contacts and interracial romance. This is particularly explored by local and national leisured classes and the bourgeoisie, which display their Creole identity by exhibiting artistic propensities through fashionable cultural manifestations, and celebrate them at festivals like Regards sur Cours, which is mostly attended by the elites, tourists and expats. ${ }^{42}$

41 After the nomination, I went on a short field incursion to Cidade Velha in Praia Island in Cape Verde. I was surprised to note that, if the application package for UNESCO was based on the idea of the island as the first African diaspora (underlying the fact that Rua Direita - "Straight Street" - was the first European street in Africa, and thus the older and inaugurator site of slave exportation), this is not reflecting in anyway on tourist marketing or featured products.

42 This is an annual art exhibition (supported last year by the Dapper Foundation and other foreign sponsors) that has been promoted since 2003 by Marie-José Crespin - a signare descendant. Her son, Xavier Ricou (author of Trésors de l'iconographie du Sénégal Colonial, Paris, Riveneuve Eds., 2003) depicted their genealogy as follows: "Je suis de la famille Crespin. Une famille qui est arrivée au Sénégal durant la Révolution Française de 1789. Mon arrière grand-parent Benjamin Crespin, qui est venu de La Rochelle, faisait le commerce de la glace. Il s'est installé au Sénégal et a épousé une Signare du nom de Cathy Couc. Avec sa Signare, ils ont eu beaucoup d'enfants, dont une fille qui a épousé un Der Neville d'une autre famille métisse. Ils ont deux autres garçons qui sont mariés à des Signare. L'un d'eux, Germain Crespin est le père de l'ancien Maire de Saint-Louis, Jean Jacques Crespin. Et c'est de fil en aiguille jusqu'à ma mère qui s'appelle Marie-José Crespin”. For his views about the responsibility of African kings in the Atlantic trade I consulted < http://www.rewmi.com/xavier-ricou-architecte-la-part-de-responsabilit e-des-rois-africains-dans-la-traite-atlantique_a3725.html > (last access April 2018, no longer available). 
The allure of UNESCO branding as a mark of cosmopolitan distinction encouraged a focus on culture as resource and capital accumulation that captivates outsiders and the local bourgeoisie. This depiction of the island is also activated for official visits and protocol when foreign presidents and delegations visit the island and ceremonial receptions are led by signares in fancy dresses (not naked slaves) even if the parade destination is the House of Slaves. This romantic depiction fits well with UNESCO and heritage regimes, while it clearly denounces the ambivalence of its rhetoric and procedures: one that invokes and re-utters the violence of the past to stage it in a remixed and controlled fashion.

The heritage regime in Senegal seems to favour this picturesque view of the signares and the island, which the educational strand of UNESCO also supports. ${ }^{43}$ It is this ambiguous and tamed framing of the past that paves the way to oblivion and forgiveness.

Every Wednesday Gorée receives students of different grade levels and ages on compulsory school visits. The House of Slaves is then transformed into a classroom for master classes in history of Africa and slavery, undeniably inspired on the successful model as performed by Joseph N'Diaye. Gorée gets back the emotional fluxes after their travels around the world, and young Africans learn, in their turn, how to be citizens of the international community on its terms: "Non pour oublier! Oui pour pardoner!" is the watchwords that the young students repeat under the curator's/teacher's command, as I could observe and register. ${ }^{44}$

\section{NATIONAL PLOTS: THE PORTUGUESE CASE}

What presidents say in Gorée is, of course, to be heard at home. Thus, Gorée is not only part of a universal history but an important symbol and a stage on which to perform national statements and shape citizen profiles for global subjects. However, it must also at the same time be viewed as a place to perform and overlook nations conformity with universal human rights. The pervasiveness of world heritage rhetoric is rooted, like the national one, in the continuous production of imagery, practices, discourses and institutions that sustain its principles. Malešević says that the nationalist process works in two directions, "on the one hand, the existence of a large nationalist meta-narrative is often utilized by local actors and various small groups that map their

43 TFM (Télé Futurs Medias), Signares filme historique, < https:/www.youtube.com/watch?v=jsyeHRmz KoY $>$ (last access June 2021). Moreover, signares are promoted as a symbol of Senegal's contemporary women's entrepreneurship: < https://www.youtube.com/watch?v=DG-dFzti2ZY > (last access June $2021)$.

44 “One day trip to Gorée Island", 2009, 8’06”. Fieldwork video by the author @CRIA/Maria Cardeira da Silva. Available at < https://youtu.be/uAysQQvaCcU > (last access June 2021). 
own individual or collective grievances by articulating in staunchly nationalist terms" (201 1: 286) and on the other hand, "to successfully mobilize popular support, the social organizations adopt the guise and rhetoric of micro-solidarity [i.e. family]" (idem: 287). The world heritage regime (especially with regard to intangible heritage) opens a third way for the exercise of this "nationalist" procedure: one that, while restoring and expanding the rhetoric strength of family ties to humankind, disregards national boundaries, and thus goes, not only beyond, but, we could say, against nation itself.

Along with the South-South Cooperation networks that I mentioned above, others seem even more indulgent with respect to colonial history of enslavement. ${ }^{45}$ On the occasion of the 2006 celebrations of Portugal Day (a Portuguese public holiday on $10^{\text {th }}$ of June), the Portuguese ambassador unveiled a plaque celebrating the passage of Portuguese navigators in the $15^{\text {th }}$ century. It was placed on the wall of the Gorée police station, allegedly a Portuguese church built in 1482. The then Senegalese minister for International Cooperation said that Gorée was the symbol of the long-standing relations between Africa and Europe. He asked for a greater understanding of the emigration of young Africans to Europe to be shown on the part of Europe, especially Portugal, which is, he pointed out, historically and geographically, Senegal's closest European country. Pilgrimage certificates were, as usual in diplomatic choreography, given to foreign political deputies. ${ }^{46}$

Later on, in 2008, Gorée was twinned with Lagos (Algarve, Portugal), the birthplace of Dinis Dias, the first European navigator to reach Gorée (then called ilha da Palma). There is a very old building in Lagos that is still considered (without any historical justification) to have been a marketplace of slaves who presumably came from the area that is now Senegal. ${ }^{47}$ Both the mayor of Gorée and the team from Lagos seemed genuinely committed to developing joint activities under the formal umbrella of town twinning. This was made evident in the words both sides proffered at the ceremony. The Portuguese mayor said: "We in Lagos wish to signalise the facts of our history built on the Age of Discovery, and even though we have kept the memory of the first slave marketplace, we are certain that Portugal was one of the first countries to end

45 Consulted at < http://www.culture.gouv.sn/?q=accord-de-jumelage-signe-entre-la-maison-des-escla ves-de-Gorée-et-du-musee-robben-island-de-lafrique > (last access April 2018, no longer available).

46 Available at < http://www.panapress.com/Portugal-celebra-passagem-por-Senegal--3-412835-51-la ngl-index.html > (last access June 2021).

47 In his Crónica da Guiné (1452-1453?), Gomes Eanes de Zurara dramatically describes the arrival of slaves at Lagos (Portugal): "[...] Some hung their heads, their faces awash with tears as they looked at one another; others groaned in distress and looked up at the sky [...]; others kept slapping their faces and throwing themselves onto the ground; others expressed their sorrow in song as was the custom in their land and although we couldn't understand the words of their language, the degree of their misery was understood $[\ldots] "$. 
that practice $[. .$.$] We have not always enjoyed the best of relations with Gorée,$ but now we are prepared for a future of fraternal friendship." For his part, the mayor of Gorée said that "Portugal was after all at the origin of Gorée seeing that it wasn't just a Portuguese navigator who first came to our country, it was one from Lagos $[\ldots]$ and even though the people of Gorée are multicultural, the first and the most important influence will always be Portugal". ${ }^{48}$

Meanwhile, the Seven Wonders of Portugal contest was launched in 2008 by a historian from Coimbra with the support of the Portuguese government. An online petition signed by some Brazilian and Portuguese historians circulated among academics and eventually triggered public debate about slavery. The petition drew attention to the fact that "when describing these sites (of slavery), the organization of the contest omitted the history of these places and the use they had during the period of the Atlantic slave trade. In the text describing the Elmina Castle, they state that this site served as slave warehouses only after the Dutch occupation in 1637." In fact, the Portuguese had begun slave trafficking a long time before. The petition signers urged "all those who are concerned about the research on slavery and the Atlantic slave trade to disagree with the attempt to diminish and erase the history of this commerce, in order to exalt a glorious Portuguese past expressed in the architectural 'beauty' of these sites of death and tragedy".

As we shall see, Portugal could officially avoid the subject until very recently even if, meanwhile, it paradoxically supported the Cidade Velha World Heritage file based on the pioneering origin of the African diaspora that began with the Portuguese slave trade (the "shameful trade" as it has often been called).

Between the events I have referred to above, a growing civil mobilization against racism and the whitewashing of slavery has paved the way for anti-racism grassroots movements and associations. In 2016, under the socialist government, the creation of a slavery memorial in the city of Lisbon was finally approved. In fact, this was a bottom-up project which won the city of Lisbon's municipal participatory budget competition. In the same year, Lagos announced a new museographic centre so that the "terrible legacy of slavery will not fall into oblivion". 49

In 2017 the current Portuguese president finally followed in the footsteps of all other eminent people who visited the island and went to Gorée. This created great expectations especially among African descendants and anti-racism activists who, for the first time, thought that the slavery issue could no longer be evaded under the nationalistic rhetoric of luso-tropicalism.

48 Page consulted and transcribed in March 2013, not retrieved after 2016.

49 Available at < http://www.sulinformacao.pt/2016/06/lagos-abre-nucleo-museologico-para-que-naose-apague-memoria-do-legado-terrivel-da-escravatura/ > (last access June 2021). 
Luso-tropicalism is an exceptionalist narrative concerning the colonial legacy of Portuguese history, ${ }^{50}$ based on an allegedly humanist pioneerism which was popularized during the Estado Novo (i.e., Salazar's New State regime, especially from the 1950s onwards) in order to mobilize national opinion in favour of its colonial project and to react against international organizations (particularly the UN) when colonialism began to be officially rejected. This is something that is still embedded in national rhetoric and facilitates, among other things, not only a denial of the truth and obliviousness with regard to Portuguese "pioneerism" in slave trade, but also the re-enactment of the colonial past through the idea of lusophonia and the political creation of international coalitions following imperial designs, such as the PALOP (African Countries of Portuguese Official Language).

The hopes of Portuguese Afro-descendants and anti-racism activists were dashed: during his visit to the House of Slaves, Marcelo Rebelo de Sousa, the Portuguese president, not only failed to ask for forgiveness when he was in Gorée but he also unveiled a commemorative plaque that was the largest in comparison to those previously offered by other presidents or political delegations. ${ }^{51}$ This provoked a great deal of contestation in Portugal, which was expressed in an open letter to the president and the spreading of a "Not in Our Name" protest tag. ${ }^{52}$ Both initiatives were explicitly claiming the primacy of citizenship over nationality and this became very clear when most of its proponents contested the concurrent project of another memorial project planned in Lisbon: that of the tentatively named Museum of Discoveries, which would tell the story of heroic Portuguese navigators who first charted routes around the world, a history that involves colonialism and slave trade.

\section{WORDS AND EMOTIONS, NATIONAL AND COSMOPOLITAN MEMORIES}

Neoliberalism policies have placed a new emphasis on communities as an innovative way to make sense of collective existence and to make it calculable and administrable. Intangible heritage, while representing a shift away from territorial definition of heritage, becomes a fundamental tool for the constitution

50 Lusotropicalism was actually a concept proposed by Gilberto Freire - a well-known Brazilian ideologist - to glorify the virtues of Brazilian hybridism and support multiculturalism. According to him, the historical roots of lusotropicalism were to be found in the multicultural stratigraphy of Portugal's own national history. It was this legacy of genuine tolerance that later on softened Portuguese colonialism and produced what he called Lusotropicalism (see, among many others, Castelo 1998 and Vale de Almeida 2000).

51 See $<$ https://www.gettyimages.pt/fotos/maisons-des-esclaves? mediatype=photography\&phrase $=$ maisons\%20des\%20esclaves\&sort $=$ mostpopular $>$. Images with restrictions use (last access June $2021)$.

52 Available at < https://www.dn.pt/portugal/interior/um-regresso-ao-passado-em-goree-nao-em-nosso -nome-6228800.html > (last access June 2021). 
of de-territorialised collectivities around residual culture (Hafstein 2007: 92, 95) and, I should add, enables imagined kinships to become major criteria to naturalize human beings and normalize belongings. What is being mobilized in UNESCO projects is something similar to the national template based on Western notions of collectively grounded kinship metaphors that make communities emotionally equivalent to families. In this imagined familial ground, emotional contradictions and paradoxes, anger and tolerance, guilt and forgiveness - in short, the normative cosmo-optimism of heritage global regime (Geismar 2015; Von Oswald, Lidchi, and MacDonald 2017) - can be better sublimated through multiculturalist conceptions in line with the "creative diversity" proposed by UNESCO, either sustained in the present or projected in the past, even when this diversity is the result of a traumatic history.

At the same time, the discursive fragments of diplomatic protocols and presidential performances that I have presented here show how nations connect with each other within the international community framework by means of the very same kinship and/or neighbourhood language, displaying or discarding emotions of hurt, revolt, shame, and pride, acting as families with their own moral codes, in (more or less) conformance with global ones.

The House of Slaves is a space of embodiment of an experience and not a space of interpretation, a space of performance and not a space of knowledge, a space of catharsis not a space of confrontation, a space of heritage and not a space of history. Heritage, as curated history, serves much better the purposes of an imagined transnational community and its normative cosmo-optimism. As in the case of Holocaust memorials (Levy and Sznaider 2002) Gorée is a paradigmatic case of a cosmopolitan memory, decontextualized from its historical time and space, that through processes of cultural mediation has turned into a universal and continually relevant moral story of good against evil. This corresponds to a transition from national to cosmopolitan memory cultures and forms of collective memory that are no longer primarily framed by the nation-state (idem 2002), and where emotions play a more important role then words. Concurrently, these atrocity memorials still serve to assert national memories through discursive speeches and historical claims, although its international exposure and scale may favour the enactment of domestic cosmopolitan memories reactive to nationalistic claims, as we have seen in the Portuguese reaction in the afore-mentioned case. In those cases, the divide between national versus cosmopolitan memories and between hot versus cold belongings seem diluted or even reversed. It is the emotional strength of the Gorée heritage and its display that supports cosmopolitan memories and their use to contest national ones. 


\section{REFERENCES}

ALMEIDA, Carla, 2012, "Ilha de Moçambique: o património e os usos da 'comunidade" ", in Maria Cardeira da Silva (org.), Castelos a Bombordo: Etnografias de Patrimónios Africanos e Memórias Portuguesas. Lisbon: Etnográfica Press, 248-260.

ANDERSON, Benedict, 1983, Imagined Communities: Reflections on the Origin and Spread of Nationalism. New York: Verso.

ARAújO, Ana Lúcia, 2010, Public Memory of Slavery: Victims and Perpetrators in the South Atlantic. Amherst, NY: Cambria Press.

ARAúJO, Ana Lúcia, 2014, Shadows of the Slave Past: Memory, Heritage, and Slavery. New York: Routledge.

BADONE, Ellen, and Sharon ROSEMAN (eds.), 2004, Intersecting Journeys: The Anthropology of Pilgrimage and Tourism. Chicago: University of Illinois Press.

BELLAGAMBA, Alice, 2009, "Back to the land of roots: African American tourism and the cultural heritage of the river Gambia", Cahiers d'Etudes Africaines, 193-194: 453-476.

BENDIX, Regina, 2021, "Verbal art and the expression of the inexpressible: making sense of sensory experience”, Etnográfica, 25 (2): 513-538.

BENDIX, Regina, Aditya EGGERT, and Arnika PESELMANN (eds.), 2012, Heritage Regimes and the State: Göttingen Studies in Cultural Property, 6. Göttingen: Universitätsverlag Göttingen.

BEnNeTt, Tony, 1995, The Birth of a Museum: History, Theory, Politics (Culture: Policy and Politics). London: Routledge.

BISSELL, William Cunningham, 2005, "Engaging colonial nostalgia”, Cultural Anthropology, $20(2): 215-248$

BOCOUM, Hamady, and Bernard TOULIER, 2013, "La fabrication du patrimoine: l'exemple de Gorée (Sénégal)”, Situ (online), 20 (2013). Available at < http://journals. openedition .org/insitu/10303 > (last access June 2021).

BRUNER, Edward M., 1996, "The representation of slavery and the return of the black diaspora”, American Anthropologist, 98 (2): 290-304.

CARIOU, Pierre-André, 1951-1952, Promenade à Gorée (Sénégal). Dakar, typescript.

CASTElO, Cláudia, 1998, "O Modo Português de Estar no Mundo": O Luso-Tropicalismo e a Ideologia Colonial Portuguesa (1933-1961). Oporto: Afrontamento.

CLÉMENT, Catherine, 1999, Afrique Esclave. Paris: Editions Agnès Vienot.

COLLINS, John, 2013, “'But what if I should need to defecate in your neighborhood, madame?': empire, redemption, and the tradition of the oppressed in a Brazilian world heritage site", Cultural Anthropology, 23 (2): 279-328.

DE ROUX, Emmanuel, 1996, "Le mythe de la Maison des Esclaves qui résiste à la réalité", Le Monde, December 27.

DIXON, Thomas, 2003, From Passions to Emotions: The Creation of a Secular Psychological Category. Cambridge: Cambridge University Press.

DIXON, Thomas, 2012, “Emotion': the history of a keyword in crisis”, Emotion Review, 4 (4): 338-344.

EADE, John, and Michael J. SALlnOW, 1991, Contesting the Sacred: The Anthropology of Christian Pilgrimage. London: Routledge.

EBRON, Paulla A., 1999, "Tourists as pilgrims: commercial fashioning of transatlantic politics”, American Ethnologist, 26 (4): 910-932. 
FINEMAN, Stephen (ed.),1993, Emotion in Organizations. London: Sage.

GEISMAR, Haidy, 2015, "Anthropology and heritage regimes", Annual Reviews of Anthropology, 44: $71-85$.

GERHARDS, Jürgen, 1989, "The changing culture of emotions in modern society", Social Science Information, 28: 737-754.

GILroy, Paul, 1993, The Black Atlantic: Modernity and Double Consciousness. Cambridge, MA: Harvard University Press.

GRABURN, Nelson, 1989, "Tourism: the sacred journey", in Valene Smith (ed.), Hosts and Guests: The Anthropology of Tourism. Philadelphia: University of Pennsylvania Press, 17-32.

GUPTA, Pamila, 2009, "Romancing the colonial on Ilha de Mozambique", Emotion in Motion: The Passion of Tourism, Travel and Movement. Conference Proceedings. Leeds, UK: Centre for Tourism and Cultural Change - Leeds Metropolitan University.

HAFSTEIN, Valdimar, 2007, "Claiming culture: intangible heritage inc., folklore, traditional knowledge", in Dorothee Hemme, Markus Tauschek and Regina Bendix (eds.), Prädikat "Heritage": Wertschöpfungen aus Culturellen Ressorcen. Munster: Lit Verlag, 75-100.

HINCHMAN, Mark, 2006, "House and household on Gorée, Senegal, 1758-1837", Journal of the Society of Architectural Historians, 65 (2): 166-187.

HOWES, David, 2003, Sensual Relations: Engaging the Senses in Culture and Theory. Ann Arbor, MI: University of Michigan Press.

LEITÃO, Francisco, 2012, Paraísos Cruzados: Itinerários Simétricos em Carabane, Uma Ilha Turística no Sul do Senegal. Lisbon: NOVA FCSH, master thesis in Anthropology.

LEPECKI, André, 2016, Singularities: Dance in the Age of Performance. London and New York: Routledge.

LEVY, Daniel, and Natan SZNAIDER, 2002, "Memory unbound: the holocaust and the formation of cosmopolitan memory", European Journal of Social Theory, 5 (1): 87-106.

LUTZ, Catherine, 1988, Unnatural Emotions: Everyday Sentiments on a Micronesian Atoll and Their Challenge to Western Theory. Chicago: The University of Chicago Press.

LUTZ, Catherine, and Geoffrey M. WHITE, 1986, “The anthropology of emotions”, Annual Review of Anthropology, 26 (4): 910-932.

LUTZ, Catherine, and Lila ABU-LUGHOD (eds.), 1990, Language and the Politics of Emotion. Cambridge: Cambridge University Press.

MALEŠEVIĆ, Sinisa, 2011 , "The chimera of national identity", Nations and Nationalism, 17 (2): 272-290.

MAUSS, Marcel, and Henri HUBERT, 1902-1903, “Esquisse d'une théorie générale de la magie", L'Année Sociologique, 7: 1-146.

MEYER, Birgit, and Marleen WITTE, 2013, "Heritage and the sacred: introduction", Material Religion: The Journal of Objects, Art and Belief, 9: 274-280.

MORINIS, Alan (ed.), 1992, Sacred Journeys: The Anthropology of Pilgrimage. Westport, CT: Greenwood Press.

NASH, Kate, 2003, “Cosmopolitan political community: why does it feel so right?", Constelations, 10 (4): 506-518.

NGOM, Fallou, 2012, "Popular culture in Senegal", in Toyin Falola and Tyler Fleming (eds.), Music, Performance and African Identities. London: Routledge, 97-124.

PICARD, David, 201 1, Tourism, Magic and Modernity: Cultivating the Human Garden. New York: Berghahn Books. 
PICARD, Michel, 1990, "Cultural tourism in Bali: cultural performances as tourist attraction”, Indonesia, 49: 37-74.

PLAMPER, Jan, 2015, The History of Emotions: An Introduction. Oxford: Oxford University Press.

REDDY, William, 2001, The Navigation of Feeling: A Framework for the History of Emotions. Cambridge: Cambridge University Press.

RICHARD, Anker, and Nathalie CARON, 2014, "Sécularisation et transferts du religieux: de la fin de la religion à l'ouverture indécise”, Revue Française d'Etudes Américaines, 4 (141): 3-20.

RICOU, Xavier, 2003, Trésors de l'iconographie du Sénégal colonial. Paris: Riveneuve Eds.

ROSALDO, Michelle, 1984, "Toward an anthropology of self and feeling", in Richard Shweder and Robert LeVine (eds.), Culture Theory: Essays on Mind, Self and Emotion. Cambridge: Cambridge University Press, 137-157.

ROSENWEIN, Barbara H., 2006, Emotional Communities in the Early Middle Ages. Ithaca, NY, and London: Cornell University Press.

SANTOS, Boaventura de Sousa, 1997, "Por uma concepção multicultural dos direitos humanos”, Revista Crítica de Ciências Sociais, 48: 11-32.

SENGHOR, Léopold S., 1964, Liberté 1: Négritude et humanisme. Paris: Seuil.

SIEBEN, Barbara, and Ása WETTERGREN, (eds), 2010, Emotionalizing: Organizations and Organizing Emotions. Basingstoke: Palgrave Macmillan.

SINGLETON, Theresa, 1999, "The slave trade remembered on the former gold and slave coasts", Slavery \& Abolition, 20 (1): 150-169.

SOLOMON, Robert C., 1984, "Getting angry: the Jamesian theory of emotion in Anthropology”, in Richard Schweder and Robert LeVine (eds.), Culture Theory: Essays on Mind, Self and Emotion. Cambridge: Cambridge University Press, 238-254.

SOLOMON, Robert C., 1988, "On emotions as judgments", American Philosophical Quarterly, 25 (2): 183-191.

STEARNS, Carol Z., and Peter N. STEARNS, 1988, Emotions and Social Change. New York: Holmes and Meier.

STOLER, Ann Laura, 2008, "Imperial debris: reflections on ruins and ruination", Cultural Anthropology, 23 (2): 191-219.

TURNER, Bryan S., 2000, "Liberal citizenship and cosmopolitan virtue", in Andrew Vandenberg (ed.), Citizenship and Democracy in a Global Era. Houndmills, Basingstoke, Hampshire: Macmillan Press, 18-32.

UNESCO, 2014, The Slave Route: 1994-2014. The Road Travelled. Paris: Culture Sector History and Memory for Dialogue Section.

VALDERRAMA MARTínEZ, Fernando, 1995, A History of UNESCO. Paris: UNESCO.

VAle De AlMEIDA, Miguel, 2000, Um Mar da Cor da Terra: "Raça”, Cultura e Política da Identidade. Oeiras: Celta.

VON OSWALD, Margareta, Henrietta LIDCHI, and Sharon MACDONALD, 2017, "Engaging anthropological legacies toward cosmo-optimistic futures?", Museum Worlds: Advances in Research, 5: 97-109.

WERBNER, R., 1998, Memory and the Postcolony: African Anthropology and the Critique of Power. London: Zed Books.

WEST, Patrick, 2004, Conspicuous Compassion: Why Sometimes it Really is Cruel to Be Kind. London: Civitas, Institute for the Study of Civil Society. 
WUlfF, Helena (ed.), 2007, The Emotions: A Cultural Reader. Oxford: Berg Publishers.

Receção da versão original / Original version

$2019 / 03 / 11$

Aceitação / Accepted

$2020 / 01 / 10$ 